\title{
Strategic grazing management and nitrous oxide fluxes from pasture soils in tropical dairy systems
}

\author{
Guilhermo F.S. Congio ${ }^{\text {a,* }}$, Marília B. Chiavegato a , Camila D.A. Batalha ${ }^{\text {a }}$, Patrícia P.A. Oliveira ${ }^{\text {b }}$, \\ Thomas M.R. Maxwell ${ }^{\text {c }}$, Pablo Gregorini ${ }^{\text {c}}$, Sila C. Da Silva ${ }^{\text {a }}$ \\ a Animal Science Department, University of São Paulo, “Luiz de Queiroz" College of Agriculture (USP/ESALQ), Piracicaba, São Paulo, Brazil \\ b Embrapa Pecuária Sudeste, São Carlos, São Paulo, Brazil \\ c Faculty of Agriculture and Life Sciences, Lincoln University, Christchurch, New Zealand
}

\section{H I G H L I G H T S}

- The study regards $\mathrm{N}_{2} \mathrm{O}$ fluxes from pasture soils as influenced by grazing strategies.

- More frequent defoliation ( $\mathrm{LL}_{95 \%}$ ) does not increase $\mathrm{N}_{2} \mathrm{O}$ fluxes from pasture soils.

- Strategic grazing decreases $34 \%$ the Nurea applied per unit of milk production.

- Strategic grazing decreases $40 \%$ the $\mathrm{N}_{2} \mathrm{O}$ emission per unit of milk production.

- Strategic grazing is a non-cost and provides intensification of systems resources.

\section{A R T I C L E I N F O}

\section{Article history:}

Received 12 November 2018

Received in revised form 13 March 2019

Accepted 12 April 2019

Available online 13 April 2019

Editor: Ouyang Wei

\section{Keywords:}

Canopy light interception

Nitrous oxide fluxes

Grazed soils

Soil nitrogen

Sustainable intensification

Elephant grass

\section{G R A P H I C A L A B S T R A C T}

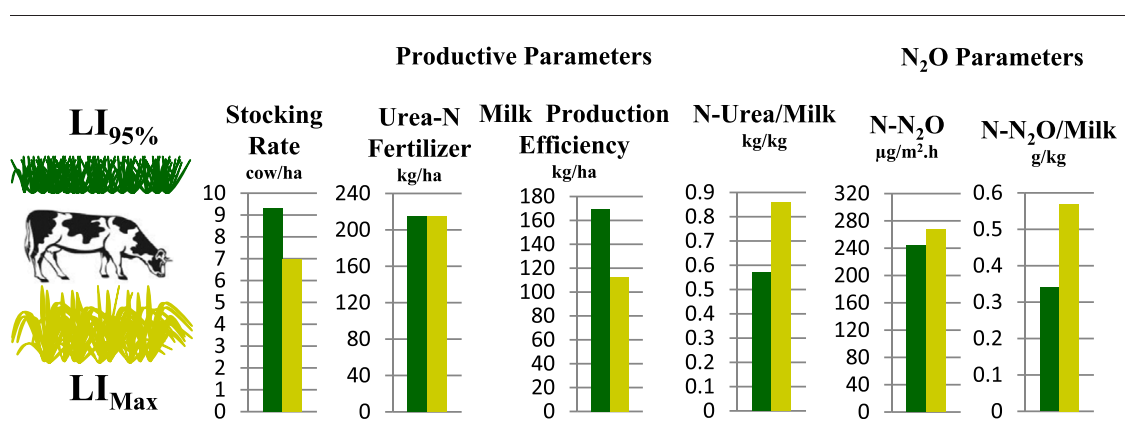

\section{A B S T R A C T}

Greenhouse gases emissions are considered one of the most important environmental issues of dairy farming systems. Nitrous oxide $\left(\mathrm{N}_{2} \mathrm{O}\right)$ has particular importance owing to its global warming potential and stratospheric ozone depletion. The objective of this study was to investigate the influence of two rotational grazing strategies characterized by two pre-grazing targets (95\% and maximum canopy light interception; $\mathrm{LI}_{95 \%}$ and $\mathrm{LI}_{\mathrm{Max}}$, respectively) on milk production efficiency and $\mathrm{N}_{2} \mathrm{O}$ fluxes from soil in a tropical dairy farming system based on elephant grass (Pennisetum purpureum Schum. cv. Cameroon). Results indicated that $\mathrm{LI}_{95}$ pre-grazing target provided more frequent defoliations than $\mathrm{LI}_{\text {Max }}$. Water-filled pore space, soil and chamber temperatures were affected by sampling periods $\left(\mathrm{P}_{1}\right.$ and $\mathrm{P}_{2}$ ). There was a significant pre-grazing target treatment $\times$ sampling period interaction effect on soil $\mathrm{NH}_{4}^{+}$concentration, which was most likely associated with urinary-N discharge. During $\mathrm{P}_{1}$, there was a greater urinary-N discharge for $\mathrm{LI}_{95 \%}$ than $\mathrm{LI}_{\mathrm{Max}}(26.3$ vs. $20.9 \mathrm{~kg}$ of urinary-N/paddock) caused by higher stocking rate, which resulted in greater $\mathrm{N}_{2} \mathrm{O}$ fluxes for $\mathrm{LI}_{95 \%}$. Inversely, during $\mathrm{P}_{2}$, the soil $\mathrm{NH}_{4}^{+}$and $\mathrm{N}_{2} \mathrm{O}$ fluxes were greater for $\mathrm{LI}_{\mathrm{Max}}$ than $\mathrm{L}_{95 \%}$. During this period, the greater urinary- $\mathrm{N}$ discharge ( $46.8 \mathrm{vs} .44 .8 \mathrm{~kg}$ of urinary-N/paddock) was likely associated with longer stocking period for $\mathrm{LI}_{\mathrm{Max}}$ relative to $\mathrm{LI}_{95 \%}$, since both treatments had similar stocking rate. Converting hourly $\mathrm{N}_{2} \mathrm{O}$ fluxes to daily basis and relating to milk production efficiency, $\mathrm{LI}_{95 \%}$ was $40 \%$ more efficient than $\mathrm{LI}_{\mathrm{Max}}$ ( 0.34 vs. $0.57 \mathrm{~g} \mathrm{~N}-\mathrm{N}_{2} \mathrm{O} / \mathrm{kg}$ milk·ha). In addition, $\mathrm{Ll}_{95 \%}$ pre-grazing target decreased urea- $\mathrm{N}$ loading per milk production by $34 \%$. Strategic grazing management represented by the $\mathrm{LI}_{95 \%}$ pre-grazing target allows for intensification of tropical pasture-based dairy systems, enhanced milk production efficiency and decreased $\mathrm{N}-\mathrm{N}_{2} \mathrm{O}$ emission intensity.

(c) 2019 Elsevier B.V. All rights reserved.

\footnotetext{
* Corresponding author.

E-mail addresses: guilhermo.congio@usp.br (G.F.S. Congio), marilia.chiavegato@usp.br (M.B. Chiavegato), camila.delveaux@usp.br (C.D.A. Batalha), patricia.anchao-oliveira@embrapa.br (P.P.A. Oliveira), tom.maxwell@lincoln.ac.nz (T.M.R. Maxwell), pablo.gregorini@lincoln.ac.nz (P. Gregorini), siladasilva@usp.br (S.C. Da Silva).
} 


\section{Introduction}

Dairy farming systems provide essential high-quality protein, a major component of human diet (O'Brien et al., 2012; Aguirre-Villegas et al., 2017). Pasture-based systems are important milk suppliers to dairy industry in temperate (Chapman, 2016; Macdonald et al., 2017) and tropical climate regions (Santos et al., 2014) and thereby will play relevant role to meet world's growing demand (Godfray et al., 2010; Conforti, 2011; Alexandratos and Bruinsma, 2012).

The key to understanding the principles used to conceive grazing management strategies is to comprehend that the harvestable components are photosynthetic organs - predominantly leaves (Parsons et al., 2011). Studies have reported that grazing management strategies based on canopy critical leaf area index (i.e. LAI that allows for the interception of $95 \%$ of the incident light) minimize stem elongation and prioritize leaf rather than other plant component accumulation, corresponding to an useful tool for planning and managing efficient pasture-based systems in the tropics (Da Silva et al., 2017; Sbrissia et al., 2018). Leafy swards mean high herbage quality, since it provides high rates of herbage intake by grazing animals, as leaves require less strength to be harvested, and because they have greater nutritive value than stems and dead material (Trindade et al., 2007). In this sense, the development of efficient pasture-based systems of animal production with perennial tropical grasses usually focuses on the control of stem elongation and excessive senescence and dead material accumulation through adequate grazing management strategies (Da Silva et al., 2015).

Greenhouse gases (GHG) emissions are considered one of the most important environmental issues of dairy farming systems (O'Brien et al., 2012; Guerci et al., 2013; Gregorini et al., 2016) and nitrous oxide $\left(\mathrm{N}_{2} \mathrm{O}\right)$ is the second most representative among all GHG, ranging from 15 to $25 \%$ of total GHG emissions in those systems (AguirreVillegas et al., 2017). Nitrous oxide is formed through soil microbial transformation of nitrogen $(\mathrm{N})$ compounds, typically by incomplete denitrification or by nitrification (Wrage et al., 2001; Saggar et al., 2013). Nitrous oxide fluxes are affected by a wide range of proximal and distal regulators, making its regulation a very complex process (de Klein et al., 2008; Luo et al., 2017). Proximal soil factors include mineral N $\left(\mathrm{NH}_{4}^{+}\right.$ and $\mathrm{NO}_{3}^{-}$) and organic carbon availabilities, moisture, $\mathrm{pH}$, temperature, and texture that, in turn, are affected by distal regulators such as rainfall or irrigation, soil compaction, organic matter and $\mathrm{N}$ inputs (de Klein et al., 2008; Luo et al., 2017). Periods when soil characteristics coincide for favorable $\mathrm{N}_{2} \mathrm{O}$ production are called "hot moments" (Luo et al., 2017). In tropical conditions, "hot moments" usually occur during spring and summer when pastures are intensively growing owing to the abundance of solar radiation, rainfall, and $\mathrm{N}$ inputs.

Grazing management strategies can strongly affect the majority of distal regulators. It determines ecophysiological plant processes such as herbage growth, senescence and decay (Da Silva et al., 2009; Pereira et al., 2014; Pereira et al., 2015; Da Silva et al., 2015; Congio et al., 2018) that strongly affect animal responses such as herbage intake (Congio et al., 2018), herbage losses by cattle trampling (Carnevalli et al., 2006; Silveira et al., 2013; Congio et al., 2018), stocking rate (Voltolini et al., 2010; Gimenes et al., 2011; Congio et al., 2018), excreta spatial distribution (White et al., 2001; Auerswald et al., 2010) and N load into pastures (Vibart et al., 2017). These factors, in turn, modify soil properties (i.e. bulk density, moisture, temperature, $\mathrm{pH}$, aeration) (Warren et al., 1986; Silva et al., 2003; Schmalz et al., 2013) that affect microbial community growth and activity (Bardgett et al., 1996; Bardgett et al., 2001; Bardgett and Wardle, 2003) determining the intensity of processes associated with $\mathrm{N}_{2} \mathrm{O}$ fluxes from soils (de Klein et al., 2008; Levine et al., 2011; Luo et al., 2017).

The majority of studies involving $\mathrm{N}_{2} \mathrm{O}$ fluxes from pasture soils have been addressed to assess the effects of proximal factors on processes and emission factors in temperate climate conditions (Saggar et al., 2013; de Klein et al., 2014; Barneze et al., 2015; Venterea et al., 2015;
Gardiner et al., 2016; Samad et al., 2016; Clough et al., 2017; Gardiner et al., 2017; van der Weerden et al., 2017; Luo et al., 2018; Rex et al., 2018). The little information available for tropical pastures has also been focused on nitrous oxide fluxes related to proximal factors within urine patches (Barneze et al., 2014; Lessa et al., 2014; Mazzetto et al., 2014; Mazzetto et al., 2015). There is no information available regarding the influence of grazing management strategies on $\mathrm{N}_{2} \mathrm{O}$ fluxes from soils of tropical pasture-based dairy farming systems. In fact, farming scale studies are scarce even in temperate climate conditions. Experimental approaches have shown that intensively managed grasslands are stronger sources of $\mathrm{N}_{2} \mathrm{O}$ than extensively managed grasslands owing to greater inputs of $\mathrm{N}$ fertilizer and excreta (Smith et al., 2001; Flechard et al., 2007; Rafique et al., 2011). However, they have not accounted for milk production efficiency that is usually greater in intensively managed systems and could decrease the intensity of $\mathrm{N}_{2} \mathrm{O}$ emission (i.e. $\mathrm{g}$ $\mathrm{N}-\mathrm{N}_{2} \mathrm{O} / \mathrm{kg}$ milk· ha $\cdot$ day).

The objective of this study was to investigate the influence of two rotational grazing strategies characterized by two pre-grazing targets (95\% and maximum canopy light interception during sward regrowth; $\mathrm{LI}_{95 \%}$ and $\mathrm{LI}_{\mathrm{Max}}$, respectively) on milk production efficiency and $\mathrm{N}_{2} \mathrm{O}$ fluxes from soil in a tropical dairy farming system based on elephant grass (Pennisetum purpureum Schum. cv. Cameroon). The general hypothesis was that frequent defoliations generated by the $\mathrm{LI}_{95 \%}$ pregrazing target would increase milk production efficiency and decrease $\mathrm{N}_{2} \mathrm{O}$ emission intensity.

\section{Material and methods}

All procedures for this study were approved by the Animal (15.5.1246.11.2) and Environment Ethics Committees (17.5.999.11.9) at the University of São Paulo, College of Agriculture "Luiz de Queiroz" (USP/ESALQ).

\subsection{Study site}

The experiment was conducted in Piracicaba, SP, Brazil $\left(22^{\circ} 42^{\prime} \mathrm{S}\right.$, $47^{\circ} 38^{\prime} \mathrm{W}$ and 546 a.s.l.) on a rainfed, non-irrigated elephant grass (Pennisetum purpureum Schum. cv. Cameroon) pasture established in 1972 in a Eutroferric Red Nitossol soil (NVef; EMBRAPA, 2018) (Table 1). The climate is sub-tropical with dry winters and $1328 \mathrm{~mm}$ average annual rainfall (CEPAGRI, 2012). The lowest and highest mean air temperatures were recorded in July $\left(19.7^{\circ} \mathrm{C}\right)$ and December $\left(27.1^{\circ} \mathrm{C}\right)$, respectively. The greatest accumulated rainfall was observed from late spring to summer (1090 mm from November 2015 to March 2016), and the lowest from winter to early spring ( $356 \mathrm{~mm}$ from June to October 2015).

\subsection{Treatments and experimental design}

The two treatments were pre-grazing targets of either 95\% or maximum canopy light interception during regrowth $\left(\mathrm{LI}_{95 \%}\right.$ and $\mathrm{LI}_{\mathrm{Max}}$, respectively). The 2.5 ha experimental area was comprised of 12 adjacent elephant grass paddocks $\left(2100 \mathrm{~m}^{2}\right.$ on average). Paddocks were assigned to treatments according to a randomized complete block design (slope and chemical soil characteristics were considered as blocking criteria), with six replications. Paddocks were then divided into three sub-paddocks ( $686 \mathrm{~m}^{2}$ on average) in order to create two farmlets of 18 sub-paddocks each where two groups of dairy cows were allocated as grazing herd throughout the experimental period (detailed information in Congio et al., 2018).

Treatments based on canopy light interception resulted in contrasting sward structures and determined pre-grazing sward surface heights (SSH) of $100 \mathrm{~cm}\left(\mathrm{LI}_{95 \%}\right)$ and $135 \mathrm{~cm}\left(\mathrm{LI}_{\mathrm{Max}}\right)$. For both pre-grazing SSH, the herbage depletion level (post-grazing height) corresponded to $50 \%$ of the pre-grazing SSH to maintain high short-term rates of herbage intake (Fonseca et al., 2012; Carvalho, 2013). Treatments were allocated 
Table 1

Soil properties (0-10 cm layer) at the beginning of the experiment.

\begin{tabular}{|c|c|c|c|c|c|c|c|c|c|c|c|c|c|}
\hline Clay & Sand & Silt & Bulk density & $\mathrm{pH}$ & $\mathrm{OM}$ & $\mathrm{P}$ & $\mathrm{K}$ & $\mathrm{Ca}$ & $\mathrm{Mg}$ & $\mathrm{S}$ & $\mathrm{H}+\mathrm{Al}$ & CEC & BS \\
\hline $\mathrm{g} / \mathrm{kg}$ & & & $\mathrm{g} / \mathrm{cm}^{3}$ & $\overline{\mathrm{CaCl}_{2}}$ & $\mathrm{~g} / \mathrm{dm}^{3}$ & $\mathrm{mg} / \mathrm{dm}^{3}$ & & & & & & & $\%$ \\
\hline 482 & 328 & 190 & 1.34 & 4.8 & 55.2 & 49.8 & 3.3 & 40.2 & 22.7 & 8.6 & 55.5 & 121.7 & 54.4 \\
\hline
\end{tabular}

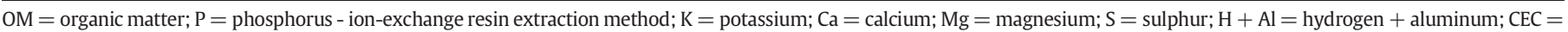
cation exchange capacity; $\mathrm{BS}=$ base saturation; the units are expressed in units of soil.

to farmlets in mid-January 2015 after grazing and mowing at 45-cm for standardization. During the 11-months prior to field measurements (mid-January to mid-December 2015), each farmlet was adapted to its respective grazing management strategy. Paddocks were rotationally grazed by $10-13$ dairy cows in order to keep grazing management targets, as specified. The adaptation period was necessary to adapt sward structure to treatments and to identify the corresponding pre-grazing $\mathrm{SSH}$ for the $\mathrm{LI}$ pre-grazing targets used ( $\mathrm{LI}_{95 \%}$ and $\mathrm{LI}_{\mathrm{Max}}$ ) (Congio et al., 2018).

Measurements were performed after the adaptation period during the second rainy season from mid-December 2015 to mid-April 2016 (experimental period). A total of $215 \mathrm{~kg} \mathrm{~N} / \mathrm{ha}$ (as urea, $45 \%$ of $\mathrm{N}$ ) was applied throughout the experimental period. Because grazing interval was not constant (as a consequence of treatments specification), the total amount of $\mathrm{N}$ to be applied was divided throughout the experimental period (119 days) and a daily rate of $\mathrm{N}$ fertilizer was calculated. The amount of $\mathrm{N}$ applied per paddock after each grazing was proportional to the length of the corresponding rest period (daily rate $\times$ rest period), ensuring similar $\mathrm{N}$ fertilizer application to both treatments at the end of the experimental period (Da Silva et al., 2017). On average, a total of $215 \mathrm{~kg} \mathrm{~N} /$ ha was divided in 3.5 and 5.6 installments for LIMax and LI95\%, respectively. Therefore, $\mathrm{N}$ inputs from urea fertilizer immediately before $\mathrm{N}_{2} \mathrm{O}$ sampling were greater for $\mathrm{LI}_{\mathrm{Max}}$ than $\mathrm{LI}_{95 \%}$ during $\mathrm{P}_{1}$ ( 75 vs. $44 \mathrm{~kg} \mathrm{~N} / \mathrm{ha}$ ) and $\mathrm{P}_{2}$ (111 vs. $\left.57 \mathrm{~kg} \mathrm{~N} / \mathrm{ha}\right)$.

Milk yield of twenty-six Holstein $\times$ Jersey dairy cows $(n=13)$ was recorded daily. An additional herd of dry-cows ( $n=10-13)$ was maintained in an adjacent area of elephant grass and was used to adjust stocking rate and keep grazing management targets constant, as needed. The stocking rate was calculated based on the number of cows used daily for each treatment, considering experimental cows and the additional herd. Milk productivity was calculated using stocking rate and milk yield for each treatment (Congio et al., 2018).

\subsection{Soil flux measurements, analysis and flux calculation}

Soil gaseous fluxes were measured using the non-ventilated closed static chamber methodology updated by the Global Research Alliance on Agricultural Greenhouse Gases (de Klein and Harvey, 2015). Gas samples, from both treatments, were collected during two sampling periods throughout the experimental period $\left(\mathrm{P}_{1}=01 / 08 / 2016\right.$ to $01 / 22$ / 2016 and $P_{2}=02 / 25 / 2016$ to 03/10/2016). Measurements were made at post-grazing, immediately after $\mathrm{N}$ fertilization, with ten chambers randomly placed 5 -cm into bare ground in each paddock $(n=10)$.

Chambers of $17.67 \mathrm{~L}$ were made of PVC, composed of a base $(30 \mathrm{~cm}$ diameter and $20 \mathrm{~cm}$ height) plus cap $(30 \mathrm{~cm}$ diameter and $10 \mathrm{~cm}$ height), and were insulated with thermal blanket to avoid heating during sampling (de Klein et al., 2014; Di et al., 2016). Chamber base and cap were sealed with rubber. Gas samples were collected immediately after chamber closing, and at 30 and $60 \mathrm{~min}$. Samples were collected from a cap sampling port using $20 \mathrm{~mL}$ plastic syringes (Becton Dickinson, Franklin Lakes, NJ, EUA) and precision glide needles (0.8 $\times 40 \mathrm{~mm}$; BD), and injected into sealed and evacuated $10 \mathrm{~mL}$ glass sample vials. Gas sampling started $24 \mathrm{~h}$ after chamber placement to allow soil microbial community to stabilize and minimize overestimation or underestimation of emissions (Chiavegato et al., 2015). Sampling was performed over five consecutive days, and then every five days until the 15 th day after $\mathrm{N}$ fertilizer was applied. Chambers were removed after $\mathrm{P}_{1}$ evaluation and re-placed following the same procedures described for $P_{1}$ at the beginning of $P_{2}$. All samples were collected from 8 to 9:15 am (Alves et al., 2012) and analyzed using gas chromatography at the Laboratory of Analytical Chemistry (Embrapa Pecuária Sudeste, São Carlos, SP, BRA).

The chromatograph GC-2014 (Shimadzu, Columbia, MD, EUA) was equipped with electron capture detectors (ECD) at $325{ }^{\circ} \mathrm{C}$ (column HayeSep T 80/100) for $\mathrm{N}_{2} \mathrm{O}$ and flame ionization detectors (FID) at $250{ }^{\circ} \mathrm{C}$ for $\mathrm{CO}_{2}$ (column HayeSep T 80/100). Calibration curves were established using standard certified gases for $\mathrm{CO}_{2}(260.2 \pm 1.77 ; 508.3$ $\pm 3.10,1058 \pm 14.49$ and $1995 \pm 10.78 \mathrm{ppm})$ and $\mathrm{N}_{2} \mathrm{O}(257.3 \pm$ $1.95 ; 502.8 \pm 3.47,999.5 \pm 17.79$ and $2328 \pm 112.67 \mathrm{ppt}$ ). Gas chromatography outputs were analyzed to determine linearity from 0 to 60 min. A strong linear relationship was observed for $\mathrm{N}_{2} \mathrm{O}\left(\mathrm{r}^{2}=0.88\right)$ and the hourly gas fluxes were calculated according to the increase of gas concentration into the headspace over sampling time (de Klein et al., 2014; Luo et al., 2018):

Gas flux $=\frac{\delta G a s}{\delta T} \times \frac{M}{V m} \times \frac{V}{A}$

where $\delta \mathrm{Gas}$ is the increase in headspace gas concentration overtime $(\mu \mathrm{L} / \mathrm{L}) ; \delta \mathrm{T}$ is the enclosure period (hours); $\mathrm{M}$ is the molar weight of $\mathrm{N}$ in $\mathrm{N}_{2} \mathrm{O} ; \mathrm{V}_{\mathrm{m}}$ is the molar volume of gas at the sampling temperature ( $\mathrm{L} /$ $\mathrm{mol}) ; \mathrm{V}$ is the headspace volume $\left(\mathrm{m}^{3}\right)$; and $\mathrm{A}$ is the area covered $\left(\mathrm{m}^{2}\right)$. Fluxes were corrected for chamber bias to account for suppression of the surface-atmosphere concentration gradient using numerical technique (Venterea, 2010) and hourly fluxes were assumed to represent mean daily fluxes (de Klein et al., 2014).

\subsection{Weather and ancillary measurements}

Atmospheric pressure, ambient temperature, and rainfall were monitored daily at the weather station located $50 \mathrm{~m}$ from the experimental area. Soil and headspace temperatures were recorded for each chamber at each time point with a digital thermometer (TE-300, Instrutherm, São Paulo, SP, BRA). Soil chemical and physical properties presented in Table 1 (except bulk density) were characterized using fifteen randomized soil subsamples per paddock collected at a $10 \mathrm{~cm}$ depth. Soil bulk density and particle density were determined using four soil cores per paddock at a $10 \mathrm{~cm}$ depth at the first day of each sampling period and calculated according to Grossman and Reinsch (2002) and Flint and Flint (2002). During the first day of sampling, additional soil samples were taken at $0-5 \mathrm{~cm}$ depth adjacent to each chamber in order to determine soil nitrate $\left(\mathrm{NO}_{3}^{-}\right)$and ammonium $\left(\mathrm{NH}_{4}^{+}\right)$. Soil $\mathrm{N}$ was extracted for $1 \mathrm{~h}$ with $2 \mathrm{M} \mathrm{KCl}$, filtered (Whatman 42) and samples were analyzed for mineral $\mathrm{N}$ concentration by flow injection analysis (ASIA; Ismatec, Zürich, Switzerland). At each sampling day prior to gas collection, soil samples were taken at $0-5 \mathrm{~cm}$ depth from the adjacent area of each chamber for soil gravimetric moisture determination $\left(24 \mathrm{~h}\right.$ at $\left.105^{\circ} \mathrm{C}\right)$. Volumetric water contents were calculated by multiplying gravimetric water contents by soil bulk density, and soil water-filled pore-space (WFPS) was calculated by dividing volumetric water content by total soil porosity (de Klein et al., 2014; Luo et al., 2018). Soil porosity was calculated according to Selbie (2013). 


\subsection{Statistical analysis}

Analysis of variance (ANOVA) was performed using the Mixed Procedure of SAS (SAS 9.3; SAS Institute Inc., Cary, NC). Different structures of the variance-covariance matrices were tested, and variance components matrix was chosen as the best fit for the majority of variables based on the Bayesian Information Criterion. The model included fixed effects of treatment, sampling period, and their interaction, and random effect of chamber. Chambers were considered experimental units and sampling periods were treated as repeated measures. All data were checked for normality and homogeneity of variances and logtransformed when they did not meet the assumptions. Soil temperature, air temperature, WFPS, soil $\mathrm{NH}_{4}^{+}$and soil $\mathrm{NO}_{3}^{-}$were tested as explanatory variables. Means were calculated using the Least-Squares Means statement, compared using the Student's $t$-test and differences were declared significant at $\mathrm{P} \leq 0.05$. For $\mathrm{N}_{2} \mathrm{O}$ fluxes, WFPS was used as a covariate. To better understand the relations among dependent variables, a principal component analysis (PCA) was performed using a data set comprised of $\mathrm{N}_{2} \mathrm{O}$ fluxes, soil $\mathrm{NH}_{4}^{+}$, soil $\mathrm{NO}_{3}^{-}$, soil temperature, chamber temperature, and WFPS. Principal components scores were submitted to ANOVA to describe and interpret the effects of treatments and periods (Jolliffe, 2002).

\section{Results}

\subsection{Weather conditions}

Weather conditions during the two sampling periods are presented in Fig. 1. Air temperature ranged from 16.6 to $35.2{ }^{\circ} \mathrm{C}$ with average of $25.7^{\circ} \mathrm{C}$ during $\mathrm{P}_{1}$ (Fig. 1A). Similarly, during $\mathrm{P}_{2}$, air temperature ranged from 18.4 to $33.3^{\circ} \mathrm{C}$ with average of $24.9^{\circ} \mathrm{C}$ (Fig. 1B). Average soil temperatures were 22.7 and $24.7^{\circ} \mathrm{C}$ for $\mathrm{P}_{1}$ and $\mathrm{P}_{2}$, respectively. Accumulated rainfall was $199 \mathrm{~mm}$ during $\mathrm{P}_{1}$ and 106 during $\mathrm{P}_{2}$ (Fig. $1 \mathrm{~A}$ and $\mathrm{B}$, respectively).

\subsection{Soil parameters}

Water-filled pore space, soil and chamber temperatures varied with sampling period $(P<0.01)$ being greater for $P_{2}$ than $P_{1}$ (Table 2$)$. Both soil $\mathrm{NH}_{4}^{+}$and $\mathrm{NO}_{3}^{-}$concentrations were not affected by treatment or sampling period $(P>0.05)$, however there was a significant interaction between treatments and sampling period for soil $\mathrm{NH}_{4}^{+}(P=0.0006)$ and a trend for soil $\mathrm{NO}_{3}^{-}(P=0.0725)$. During $\mathrm{P}_{1}$, there was an effect of $\mathrm{LI}$ pre-grazing targets on soil $\mathrm{NH}_{4}^{+}$, with greater values observed for $\mathrm{LI}_{95 \%}$ than $\mathrm{LI}_{\mathrm{Max}}$; however, during $\mathrm{P}_{2}$ soil $\mathrm{NH}_{4}^{+}$was greater for $\mathrm{LI}_{\mathrm{Max}}$ than $\mathrm{LI}_{95 \%}(P<0.05)$. Water-filled pore space and rainfall patterns for both periods are presented in Fig. 2. Days with no rainfall markedly decreased WFPS during the beginning and the end of $\mathrm{P}_{1}$ (Fig. 2A). There was no effect of LI pre-grazing target on WFPS during $\mathrm{P}_{1}(P=0.9967$; Fig. 2A), but the effect was significant during $P_{2}(P=0.05$; Fig. 2B).

\subsection{Nitrous oxide fluxes and milk production efficiency}

Nitrous oxide fluxes were strongly affected by sampling period and WFPS $(P<0.01$; Table 3$)$. On average, $\mathrm{N}_{2} \mathrm{O}$ fluxes were greater during $\mathrm{P}_{1}$ than $\mathrm{P}_{2}\left(312.8\right.$ vs. $\left.197.7 \mu \mathrm{g} \mathrm{N}-\mathrm{N}_{2} \mathrm{O} / \mathrm{m}^{2} \cdot \mathrm{hr} ; P<0.01\right)$. There was a significant interaction between treatments and sampling period $(P<$ 0.0001). During $\mathrm{P}_{1}, \mathrm{~N}_{2} \mathrm{O}$ fluxes were greater for $\mathrm{LI}_{95 \%}(P=0.0171)$ and during $\mathrm{P}_{2}$, fluxes were greater for $\mathrm{LI}_{\mathrm{Max}}(P=0.0011)$. Nitrous oxide fluxes across sampling periods and days are shown in Fig. 3. During $\mathrm{P}_{1}$, difference in $\mathrm{N}_{2} \mathrm{O}$ fluxes occurred on one day only $(1 / 10 /$ 2016), ( $P>0.05$; Fig. 3A). During $P_{2}$, two out of seven days had greater $\mathrm{N}_{2} \mathrm{O}$ fluxes for $\mathrm{LI}_{\text {Max }}$ than $\mathrm{LI}_{95 \%}(P<0.05$; Fig. 3B). Milk production efficiency was $52 \%$ greater for $\mathrm{LI}_{95 \%}$ than $\mathrm{LI}_{\mathrm{Max}}(170$ and $112 \mathrm{~kg} / \mathrm{ha} \cdot$ day for $\mathrm{LI}_{95 \%}$ and $\mathrm{LI}_{\mathrm{Max}}$, respectively; $P=0.0012$ ).
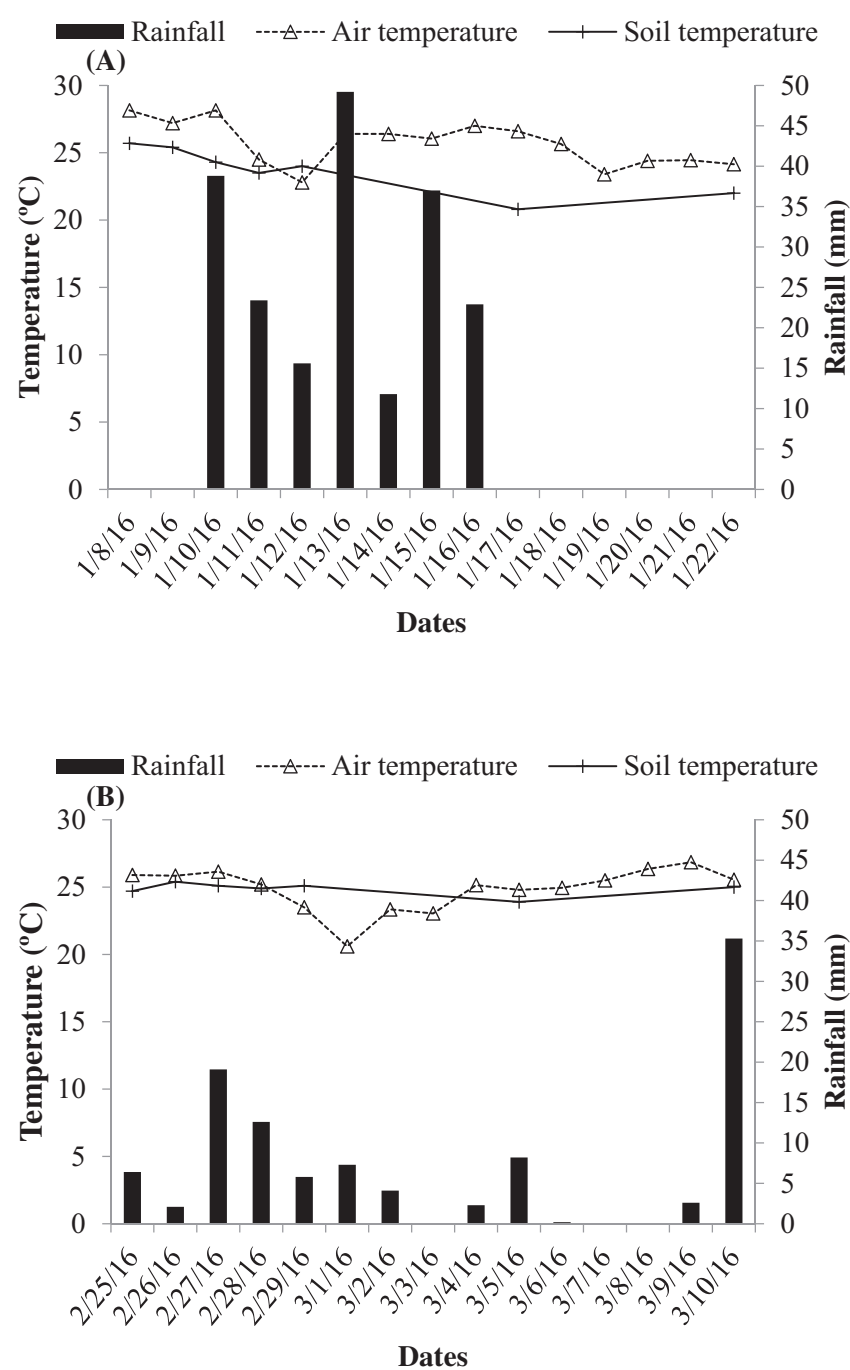

Fig. 1. Daily air and soil $\left(0-5 \mathrm{~cm}\right.$ depth) temperatures $\left({ }^{\circ} \mathrm{C}\right)$ and rainfall $(\mathrm{mm})$ during sampling periods $\mathrm{P}_{1}(\mathrm{~A})$ and $\mathrm{P}_{2}$ (B) at the study site (Jan-Mar 2016).

\subsection{Principal component analysis}

Principal component analysis generated six principal components, however, only the first two were explored because these had eigenvalues $>1$ (Kaiser criterion; Jolliffe, 2002) and accounted for $71.8 \%$ of the total variance in $\mathrm{N}_{2} \mathrm{O}$ fluxes (Table 4). The first principal component (PC1) explained $49 \%$ of the total variance and indicated high positive scores for $\mathrm{N}_{2} \mathrm{O}$ fluxes and WFPS, and high negative scores for soil and chamber temperatures. Analysis of variance on PC1 scores showed a significant effect of sampling period $(P<0.01)$. The second principal component (PC2) accounted for $22.8 \%$ of the total variance and showed high positive score for soil $\mathrm{NH}_{4}^{+}$and high negative score for soil $\mathrm{NO}_{3}^{-}$contents. Analysis of variance on PC2 scores showed a significant effect of treatment $\times$ sampling period interaction $(P=0.0015)$.

\section{Discussion}

The objective of this study was to investigate the influence of two rotational grazing strategies characterized by two pre-grazing targets on milk production efficiency and $\mathrm{N}_{2} \mathrm{O}$ fluxes from the soil in a tropical dairy farming system during a "hot moment". In tropical conditions, "hot moments" usually occur during spring and summer ( 180 days) when pastures are intensively growing owing to the abundance of 
Table 2

Water-filled pore space (WFPS), soil temperature, chamber temperature, ammonium and nitrate concentrations from soil growing elephant grass subjected to strategies of rotational stocking management ( $\mathrm{Ll}_{95 \%}$ or $\mathrm{LI}_{\mathrm{Max}}$ ) during sampling periods $\mathrm{P}_{1}(01 / 08 / 2016$ to $01 / 22 / 2016)$ and $P_{2}(02 / 25 / 2016$ to $03 / 10 / 2016)(n=10)$.

\begin{tabular}{|c|c|c|c|c|c|c|}
\hline & \multicolumn{2}{|l|}{ Period } & \multirow[t]{2}{*}{ SEM $^{\mathrm{a}}$} & \multicolumn{3}{|l|}{$P$-value } \\
\hline & 1 & 2 & & $\operatorname{Trt}^{\mathrm{b}}$ & $\operatorname{Per}^{c}$ & Trt $\times$ Per \\
\hline \multicolumn{7}{|c|}{ WFPS, \% } \\
\hline \multirow{2}{*}{$\begin{array}{l}\mathrm{LI}_{95 \%} \\
\mathrm{LI}_{\text {Max }}\end{array}$} & 77.8 & 94.5 & 1.57 & 0.1654 & $<0.0001$ & 0.1672 \\
\hline & Soil & p., ${ }^{\circ} \mathrm{C}$ & & & & \\
\hline \multirow{2}{*}{$\begin{array}{l}\mathrm{LI}_{95 \%} \\
\mathrm{LI}_{\text {Max }}\end{array}$} & 23.7 & 24.9 & 0.11 & 0.4125 & $<0.0001$ & 0.4631 \\
\hline & Chamb & emp., ${ }^{\circ} \mathrm{C}$ & & & & \\
\hline \multirow{3}{*}{$\begin{array}{l}\mathrm{LI}_{95 \%} \\
\mathrm{LI}_{\mathrm{Max}}\end{array}$} & 22.6 & 23.7 & 0.14 & 0.7344 & $<0.0001$ & 0.8221 \\
\hline & & & & & & \\
\hline & $\mathrm{NH}_{4}^{+}, \mathrm{m}$ & dry soil & & & & \\
\hline & $283.4 \mathrm{Aa}$ & $76.6 \mathrm{Bb}$ & 69.44 & 0.8771 & 0.4915 & 0.0006 \\
\hline \multirow{2}{*}{$\begin{array}{l}\mathrm{L}^{195 \%} \\
\mathrm{LI}_{\text {Max }}\end{array}$} & $21.4 \mathrm{Bb}$ & $318.4 \mathrm{Aa}$ & & & & \\
\hline & $\mathrm{NO}_{3}^{-}, \mathrm{m}$ & dry soil & & & & \\
\hline $\mathrm{LI}_{95 \%}$ & $5.0 \mathrm{Aa}$ & $20.6 \mathrm{Aa}$ & 6.18 & 0.2218 & 0.5126 & 0.0725 \\
\hline $\mathrm{LI}_{\mathrm{Max}}$ & $8.8 \mathrm{Aa}$ & $1.4 \mathrm{Ba}$ & & & & \\
\hline
\end{tabular}

Means followed by the same upper case letter in columns and lower case letter in rows do not differ $(P>0.05)$.

a Standard error of the mean.

b Treatment effect.

c Sampling period effect.
Table 3

Nitrous oxide fluxes $\left(\mu \mathrm{g} \mathrm{N}-\mathrm{N}_{2} \mathrm{O} / \mathrm{m}^{2} \cdot \mathrm{hr}\right.$ ) from soil growing elephant grass subjected to strategies of rotational stocking management $\left(\mathrm{LI}_{95 \%}\right.$ or $\left.\mathrm{LI}_{\mathrm{Max}}\right)$ during sampling periods $\mathrm{P}_{1}$ (01/08/2016 to $01 / 22 / 2016)$ and $P_{2}(02 / 25 / 2016$ to $03 / 10 / 2016)(n=10)$.

\begin{tabular}{|c|c|c|c|c|c|c|c|}
\hline & \multicolumn{2}{|c|}{$\begin{array}{l}\mathrm{N}-\mathrm{N}_{2} \mathrm{O}, \mu \mathrm{g} \\
\mathrm{N}-\mathrm{N}_{2} \mathrm{O} / \mathrm{m}^{2} \cdot \mathrm{hr}\end{array}$} & \multirow[t]{2}{*}{ SEM $^{\mathrm{a}}$} & \multicolumn{4}{|l|}{$P$-value } \\
\hline & $P_{1}$ & $\mathrm{P}_{2}$ & & $\operatorname{Trt}^{\mathrm{b}}$ & $\operatorname{Per}^{c}$ & Trt $\times$ Per & WFPS $^{\mathrm{d}}$ \\
\hline $\mathrm{LI}_{95 \%}$ & $369.6 \mathrm{Aa}$ & $117.5 \mathrm{Bb}$ & 40.10 & 0.4907 & 0.011 & $<0.0001$ & $<0.0001$ \\
\hline $\mathrm{LI}_{\mathrm{Max}}$ & $256.0 \mathrm{Ba}$ & 277.9 Аa & & & & & \\
\hline
\end{tabular}

Means followed by the same upper case letter in columns and the lower case letter in rows do not differ $(P>0.05)$.

a Standard error of the mean.

b Treatment effect.

c Sampling period effect.

d Water-filled pore space effect.

solar radiation, rainfall, and $\mathrm{N}$ inputs. Prior to the beginning of measurements, all paddocks were subjected to an 11-month adaptation period to grazing treatments (horizontal and vertical structure and dynamics pattern of plant growth and herbage accumulation) to ensure that any observed effects would be a direct consequence of the dynamics associated with each grazing strategy. Samples for $\mathrm{N}_{2} \mathrm{O}$ determination were taken as snapshots during 2 grazing cycles (sampling periods $P_{1}$ and $\mathrm{P}_{2}$ ) during periods of active and intensive plant growth and development ("hot moments") from a total of 3.5 and 5.6 grazing cycles for

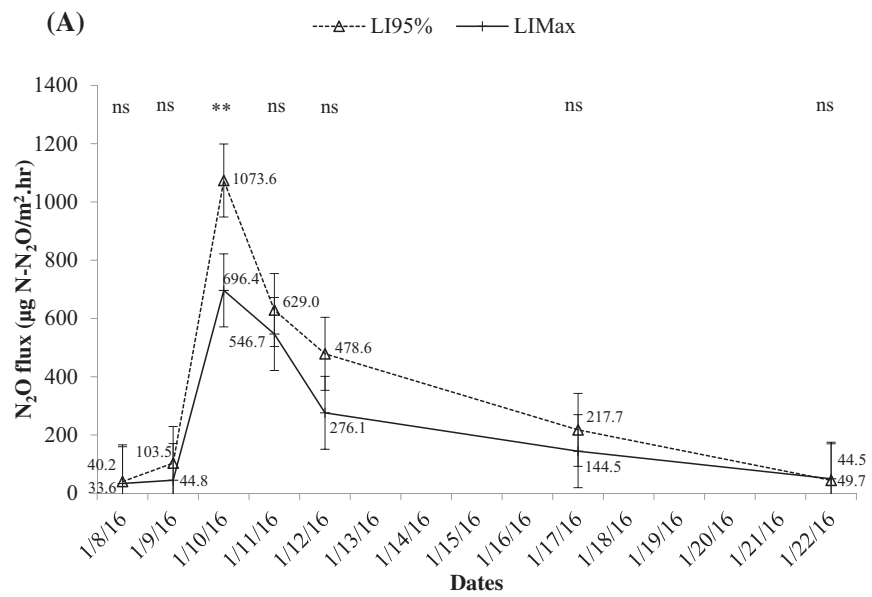

(B) $\quad \cdots$ LI95\% $\quad$ - - LIMax

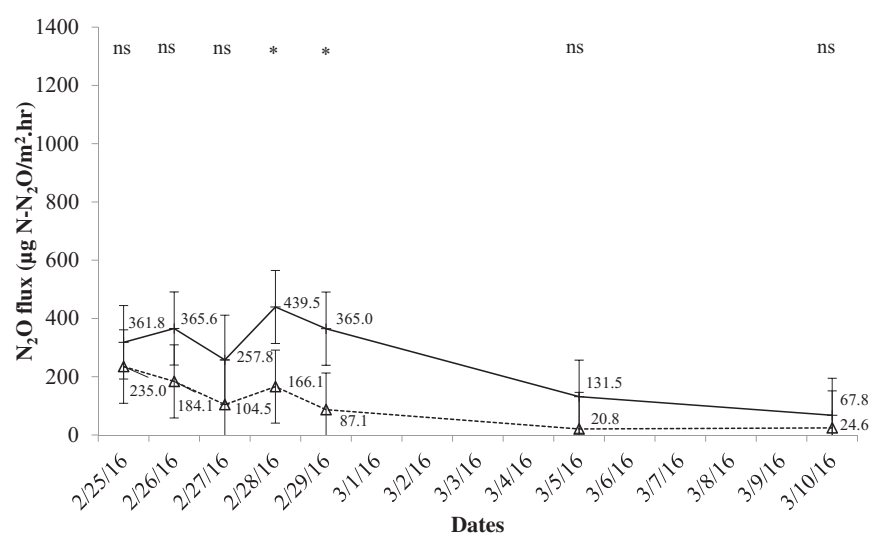

Fig. 3. Nitrous oxide fluxes ( $\mu \mathrm{g} \mathrm{N}-\mathrm{N}_{2} \mathrm{O} / \mathrm{m}^{2} \cdot \mathrm{hr}$ ) derived from soil growing elephant grass subjected to strategies of rotational stocking management $\left(\mathrm{LI}_{95 \%}\right.$ or $\left.\mathrm{LI}_{\mathrm{Max}}\right)$ during

sampling periods $\mathrm{P}_{1}(\mathrm{~A})$ and $\mathrm{P}_{2}(\mathrm{~B})$. ns $(P>0.05),{ }^{*}(P \leq 0.05),{ }^{* *}(P \leq 0.01)$
Fig. 2. Water-filled pore space (WFPS) and rainfall $(\mathrm{mm})$ during sampling periods $\mathrm{P}_{1}$

(A) and $\mathrm{P}_{2}$ (B) at the study site (Jan-Mar 2016). ${ }^{1}$ Standard error of the mean.

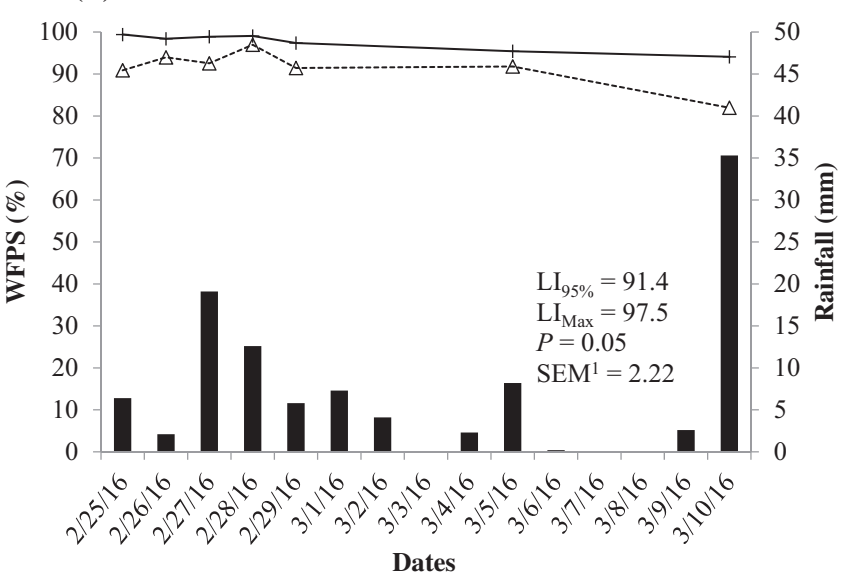




\section{Table 4}

Coefficients of principal components based on the correlation matrix for $\mathrm{N}_{2} \mathrm{O}$ fluxes, soil $\mathrm{NH}_{4}^{+}$and $\mathrm{NO}_{3}^{-}$, soil and chamber temperatures, and water-filled pore space from soil growing elephant grass subjected to strategies of rotational stocking management ( $\mathrm{LI}_{95 \%}$ or $\mathrm{LI}_{\text {Max }}$ ).

\begin{tabular}{|c|c|c|}
\hline Variables & PC1 & PC2 \\
\hline $\mathrm{N}_{2} \mathrm{O}$ fluxes & 0.49 & -0.08 \\
\hline Soil $\mathrm{NH}_{4}^{+}$ & 0.13 & 0.67 \\
\hline Soil $\mathrm{NO}_{3}^{-}$ & 0.00 & -0.70 \\
\hline Soil temperature & -0.48 & 0.19 \\
\hline Chamber temperature & -0.49 & 0.07 \\
\hline Water-filled pore space & 0.52 & 0.15 \\
\hline Eigenvalue & 2.94 & 1.37 \\
\hline$\%$ of variation explained & 49.0 & 22.8 \\
\hline ANOVA & \multicolumn{2}{|c|}{$P$-value } \\
\hline $\operatorname{Trt}^{1}$ & 0.1149 & 0.6239 \\
\hline $\mathrm{Per}^{2}$ & $<0.0001$ & 0.2950 \\
\hline Trt $\times$ Per & 0.6934 & 0.0015 \\
\hline 1 Treatment effect & & \\
\hline${ }^{2}$ Sampling period effect & & \\
\hline
\end{tabular}

$\mathrm{LI}_{\mathrm{Max}}$ and $\mathrm{LI}_{95 \%}$, which represented 57 and $36 \%$ of the entire growing periods, respectively.

The grazing management strategies used in this study provided contrasting pre- and post-grazing SSH that affected grazing interval and ultimately the number of grazing cycles. For $\mathrm{LI}_{\mathrm{Max}}$, pre- and post-grazing SSH were 135 and $64 \mathrm{~cm}$, respectively, which resulted in an average grazing interval of 32 days and 3.5 grazing cycles during the experimental period (Congio et al., 2018). On the other hand, for $\mathrm{LI}_{95 \%}$, pre- and post-grazing SSH were 100 and $50 \mathrm{~cm}$, respectively, which resulted in an average grazing interval of 21 days and 5.6 grazing cycles (Congio et al., 2018). Considering adaptation and experimental periods (from January 2015 to April 2016) there were 9.3 grazing cycles for $\mathrm{LI}_{\mathrm{Max}}$ and 14.1 for $\mathrm{LI}_{95 \%}$, indicating greater frequency of defoliation on paddocks managed with the $\mathrm{LI}_{95 \%}$ target relative to those managed with the $\mathrm{LI}_{\mathrm{Max}}$ target. To keep the pre- and post-grazing targets, the average stocking rate during the entire experimental period was 33\% greater for $\mathrm{LI}_{95 \%}$ than $\mathrm{LI}_{\mathrm{Max}}$ (9.3 vs. 7.0 cows/ha; Congio et al., 2018). These grazing conditions resulted in different scenarios of intensification, solely by changing pre-grazing targets ( $\mathrm{LI}_{95 \%}$ or $\mathrm{LI}_{\mathrm{Max}}$ ). It is worthwhile to mention that the greater stocking rate obtained in $\mathrm{LI}_{95 \%}$ was supported by greater leaf accumulation and greater grazing efficiency rather than increased $\mathrm{N}$ fertilizer input, usually applied in intensive temperate pasture-based systems (Ramsbottom et al., 2015; Macdonald et al., 2017; Congio et al., 2018).

In grazed pastoral soils, the factors pointed out as key drivers of $\mathrm{N}_{2} \mathrm{O}$ fluxes are $\mathrm{N}$ inputs (i.e. urine patches and fertilizer) and WFPS (de Klein et al., 2008; Luo et al., 2017). Nitrous oxide fluxes and soil $\mathrm{NH}_{4}^{+}$varied with $\mathrm{LI}$ pre-grazing target $\times$ sampling period interaction, while a trend was observed for $\mathrm{NO}_{3}^{-}$. On the other hand, the variables related to weather (i.e. WFPS, soil and chamber temperatures) varied only with sampling period. Most studies have indicated that high $\mathrm{N}_{2} \mathrm{O}$ emissions are usually associated with anaerobic soils with enough $\mathrm{NO}_{3}^{-}$supply suggesting that denitrification is the main process responsible for $\mathrm{N}_{2} \mathrm{O}$ emissions (de Klein and Eckard, 2008; de Klein et al., 2008). However, on excessively saturated soils with higher WFPS (i.e. optimal conditions for denitrification), as observed in $\mathrm{P}_{2}$, denitrification is complete and results in a greater $\mathrm{N}_{2}: \mathrm{N}_{2} \mathrm{O}$ ratio (Bolan et al., 2004; de Klein et al., 2008).

Although the accumulated rainfall was greater during $\mathrm{P}_{1}(199 \mathrm{~mm})$ than $\mathrm{P}_{2}(106 \mathrm{~mm})$, the WFPS was constantly greater throughout $\mathrm{P}_{2}$ than $P_{1}$. These results are likely associated with better rainfall distribution during $\mathrm{P}_{2}$, where there were $80 \%$ of rainy days, while during $\mathrm{P}_{1}$ there were just $47 \%$ of rainy days. Studies have reported that peak $\mathrm{N}_{2} \mathrm{O}$ emissions occurred at WFPS values around $60-80 \%$, when simultaneous nitrification and denitrification were at maximum levels (Davidson, 1992; Rafique et al., 2011). Above this WFPS range, denitrification is the main source of $\mathrm{N}_{2} \mathrm{O}$ and under excessively anaerobic conditions, $\mathrm{N}_{2}: \mathrm{N}_{2} \mathrm{O}$ ratio remains greater (Bolan et al., 2004; de Klein et al.,
2008; Rafique et al., 2011). The results of PCA pointed to an interaction among the driving factors regulating $\mathrm{N}_{2} \mathrm{O}$ fluxes from soil. The first PCA indicated that environmental factors (i.e. WFPS, soil and chamber temperatures) were determinants of $\mathrm{N}_{2} \mathrm{O}$ emissions and explained $49 \%$ of the whole dataset variability. Principal component analysis two showed that factors related to $\mathrm{LI}$ pre-grazing targets (i.e. soil $\mathrm{NH}_{4}^{+}$and $\mathrm{NO}_{3}^{-}$) had the highest scores and accounted for $22.8 \%$ of total variance. Flechard et al. (2007) also reported that weather factors explained half of the total variability in their $\mathrm{N}_{2} \mathrm{O}$ flux dataset of ten sites for three years across Europe. Analysis of variance on PC1 and PC2 scores corroborated the results from the analysis of variance, where environmental factors showed significant effect for sampling period, as observed in PC1, and treatment related factors showed a significant LI pre-grazing target $\times$ sampling period interaction effect, as observed in PC2.

Both soil $\mathrm{NH}_{4}^{+}$and $\mathrm{NO}_{3}^{-}$represented the concentration immediately after urea fertilization at day one, and therefore indicate $\mathrm{N}$ availability at the beginning of each sampling period. For both LI pre-grazing targets, a total of $215 \mathrm{~kg} \mathrm{~N} / \mathrm{ha}$ was applied throughout the experimental period. However, this amount was divided in 3.5 and 5.6 installments for $\mathrm{LI}_{\mathrm{Max}}$ and $\mathrm{LI}_{95 \%}$, respectively. Therefore, the $\mathrm{N}$ inputs from urea fertilizer immediately before $\mathrm{N}_{2} \mathrm{O}$ sampling were greater for $\mathrm{LI}_{\mathrm{Max}}$ than $\mathrm{LI}_{95 \%}$ during $\mathrm{P}_{1}$ and $\mathrm{P}_{2}$ (Table 5). However, there was a significant LI pre-grazing target $\times$ sampling period interaction on soil $\mathrm{NH}_{4}^{+}$concentration, most likely associated with urinary- $\mathrm{N}$ discharge. During $\mathrm{P}_{1}$, there was a greater urinary-N discharge for $\mathrm{LI}_{95 \%}$ than $\mathrm{LI}_{\mathrm{Max}}$ caused by higher stocking rate (Table 5), which resulted in greater $\mathrm{N}_{2} \mathrm{O}$ fluxes for $\mathrm{LI}_{95 \%}$. Inversely, during $\mathrm{P}_{2}$, the soil $\mathrm{NH}_{4}^{+}$and $\mathrm{N}_{2} \mathrm{O}$ fluxes were greater for $\mathrm{LI}_{\text {Max }}$ than $\mathrm{LI}_{95 \%}$. During this period, the greater urinary-N discharge was likely associated with greater stocking period for $\mathrm{LI}_{\mathrm{Max}}$ relative to $\mathrm{LI}_{95 \%}$, since both treatments had similar stocking rate (Table 5 ). These results are in agreement with most studies that have reported urine patches as the main source of $\mathrm{N}_{2} \mathrm{O}$ from grazed pasture soil mainly by providing highly localized concentrations of available N, ranging from 200 to $2000 \mathrm{~kg} \mathrm{~N} / \mathrm{ha}$, associated with increased moisture and temperature conditions (Selbie et al., 2015; Luo et al., 2018).

Dairy farming systems based in temperate pastures are usually more intensive than tropical pasture-based dairy systems (Macdonald et al., 2017; Congio et al., 2018). Temperate forage crops have been studied in depth and the understanding of their ecophysiology allowed for better use by farmers through adoption of adequate grazing management strategies, ensuring high milk production efficiency (Chapman, 2016). The intensification of such systems is usually coupled with extra inputs of $\mathrm{N}$ fertilizer to boost forage growth or with external supplementary feed, both aiming at increased stocking rate (Ramsbottom et al., 2015; Macdonald et al., 2017). In the tropics, dairy farming systems usually have low $\mathrm{N}$ inputs and adopt inadequate grazing management strategies resulting in low milk productivity (Santos et al., 2014). Therefore, the intensification of tropical pasture-based dairy systems is possible through adoption of adequate grazing strategies rather than extra $\mathrm{N}$ inputs or additional supplements, provided that minimum soil fertility to meet plant nutritional demand is ensured. The results indicated the opportunity to increase milk productivity in $52 \%$ only with adoption of strategic grazing management (i.e. $\mathrm{LI}_{95 \%}$ pre-grazing target).

\section{Table 5}

Nitrogen $(\mathrm{N})$ fertilization rate, urinary-N discharge, stocking rate and stocking period from Holstein $\times$ Jersey dairy cows grazing elephant grass subjected to strategies of rotational stocking management ( $\mathrm{LI}_{95 \%}$ or $\mathrm{LI}_{\mathrm{Max}}$ ) during sampling periods $\mathrm{P}_{1}$ and $\mathrm{P}_{2}$.

\begin{tabular}{lcccccc}
\hline & $\mathrm{P}_{1}$ & & & $\mathrm{P}_{2}$ & \\
& $\mathrm{LI}_{95 \%}$ & $\mathrm{LI}_{\mathrm{Max}}$ & & $\mathrm{LI}_{95 \%}$ & $\mathrm{LI}_{\text {Max }}$ \\
\hline N-fertilization rate, kg N/ha & 44 & 75 & & 57 & 111 \\
Urinary-N discharge, kg N/paddock & 26.3 & 20.9 & & 44.8 & 46.8 \\
Stocking rate & a cows/ha & 10.0 & 8.3 & & 9.9 & 9.5 \\
Stocking period, days & 0.88 & & 0.88 & & 1.46 & 1.88 \\
\hline
\end{tabular}

${ }^{a}$ Represents the specific stocking rates immediately before sampling periods $P_{1}$ and $P_{2}$ 
Experimental approaches have shown that intensively managed pastures are greater sources of $\mathrm{N}_{2} \mathrm{O}$ than extensively managed pastures (Flechard et al., 2007; Rafique et al., 2011). Rafique et al. (2011) reported that frequently grazed sites that applied $400 \mathrm{~kg}$ of N/ha emitted two times more $\mathrm{N}_{2} \mathrm{O}$ compared to less frequently grazed sites that used around $300 \mathrm{~kg}$ of N/ha. However, in their study, intensively managed systems were generated through greater inputs of $\mathrm{N}$ fertilizer. Although urinary- $\mathrm{N}$ excretion increased soil $\mathrm{NH}_{4}^{+}$and ultimately $\mathrm{N}_{2} \mathrm{O}$ fluxes during $\mathrm{P}_{1}$ for $\mathrm{LI}_{95 \%}$, the urinary- $\mathrm{N}$ excretion and $\mathrm{N}_{2} \mathrm{O}$ fluxes during $\mathrm{P}_{2}$ were greater for $\mathrm{LI}_{\mathrm{Max}}$ counterbalancing the emissions for the entire experimental period ( $\left.255.3 \mu \mathrm{g} \mathrm{N}-\mathrm{N}_{2} \mathrm{O} / \mathrm{m}^{2} \cdot \mathrm{hr} ; \mathrm{P}=0.4907\right)$. Converting hourly $\mathrm{N}_{2} \mathrm{O}$ fluxes to hectare and daily basis ( $\mathrm{g} \mathrm{N}-\mathrm{N}_{2} \mathrm{O} / \mathrm{ha} \cdot$ day) and relating to milk production efficiency ( $\mathrm{kg}$ milk/ha $\cdot$ day), $\mathrm{LI}_{95 \%}$ was $40 \%$ more efficient than $\mathrm{LI}_{\mathrm{Max}}$ considering emissions for the entire period ( $0.34 \mathrm{vs}$. $0.57 \mathrm{~g} \mathrm{~N}-\mathrm{N}_{2} \mathrm{O} / \mathrm{kg}$ milk $\cdot$ ha $\cdot$ day). In addition, strategic grazing management decreased urea-N loading per milk production efficiency by $34 \%$ ( 0.57 vs. $0.86 \mathrm{~g}$ urea-N/kg milk $\cdot$ ha $\cdot$ day).

In the context of growing concern about the intensification of temperate pasture-based dairy systems through greater $\mathrm{N}$ fertilizer inputs (Di and Cameron, 2016; Gregorini et al., 2016; OECD, 2017), these findings highlight an opportunity to improve the efficiency of tropical pasture-based dairy systems through optimization of natural ecological processes. Strategic grazing allows for intensification that is not coupled with increases in inputs of external resources (i.e. additional fertilizer, external supplements) but rather with efficient use of existing resources (i.e. solar radiation, rainwater, pasture, fertilizer, supplement). Strategic grazing management is a non-cost and readily available practice with easy adoption that enhances profitability of tropical pasture-based systems.

\section{Conclusions}

Nitrous oxide fluxes from grazed pastoral soils in moist-warm conditions are a very complex process regulated by environmental conditions and soil nitrogen availability. The central hypothesis that frequent defoliation provided by the $\mathrm{LI}_{95 \%}$ pre-grazing target would result in lower $\mathrm{N}_{2} \mathrm{O}$ emission intensity from soil than less frequent defoliation (i.e. $\mathrm{LI}_{\text {Max }}$ ) was confirmed. These results highlight that it is possible to intensify tropical pasture-based dairy systems through the adoption of adequate grazing strategies before using extra $\mathrm{N}$ fertilizer or supplemental feed, as is usual for temperate grazing systems. This indicates the opportunity to significantly enhance milk production efficiency from tropical pasture-based systems using strategic grazing management (i.e. $\mathrm{LI}_{95 \%}$ ) and decrease $\mathrm{N}-\mathrm{N}_{2} \mathrm{O}$ emission intensity by $40 \%$.

\section{Acknowledgments}

The authors are grateful to Fundação de Amparo à Pesquisa do Estado de São Paulo (FAPESP; grants 2014/20182-9 and 2016/220402) for financial support and scholarship, to Conselho Nacional de Desenvolvimento Científico e Tecnológico (CNPq, grant 140074/20171) and Coordenação de Aperfeiçoamento de Pessoal de Nível Superior, Brazil (CAPES, finance code 001) for scholarships, and Carlos Eduardo Jordão for his help with gas chromatograph analysis. We also acknowledge the valuable suggestions from reviewers.

\section{References}

Aguirre-Villegas, H.A., Passos-Fonseca, T.H., Reinemann, D.J., Larson, R.A., 2017. Grazing intensity affects the environmental impact of dairy systems. J. Dairy Sci. 100, 6804-6821. https://doi.org/10.3168/jds.201612325.

Alexandratos, N., Bruinsma, J., 2012. World Agriculture Towards 2030/2050. FAO, Rome http://www.fao.org/fileadmin/templates/esa/Global_persepctives/world_ag_2030_ 50_2012_rev.pdf.

Alves, B.J.R., Smith, K.A., Flores, R.A., Cardoso, A.S., Oliveira, W.R.D., Jantalia, C.P., Urquiaga, S., Boddey, R.M., 2012. Selection of the most suitable sampling time for static chambers for the estimation of daily mean $\mathrm{N}_{2} \mathrm{O}$ flux from soils. Soil Biol. Biochem. 46, 129-135. https://doi.org/10.1016/j.soilbio.2011.11.022.
Auerswald, I.C., Mayer, F., Schnyder, H., 2010. Coupling of spatial and temporal pattern of cattle excreta patches on a low intensity pasture. Nutr. Cycl. Agroecosyst. 88, 275-288. https://doi.org/10.1007/s10705-009-9321-4.

Bardgett, R.D., Wardle, D.A., 2003. Herbivore-mediated linkages between aboveground and belowground communities. Ecology 84, 2258-2268. https://doi.org/10.1890/ 02-0274.

Bardgett, R.D., Hobbs, P.J., Frostegard, A., 1996. Changes in soil fungal:bacterial biomass ratios following reductions in the intensity of management of an upland grassland. Biol. Fertil. Soils 22, 261-264. https://doi.org/10.1007/BF00382522.

Bardgett, R.D., Jones, A.C., Jones, D.L., Kemmitt, S.J., Cook, R., Hobbs, P.J., 2001. Soil microbial community patterns related to the history and intensity of grazing in submontane ecosystems. Soil Biol. Biochem. 33, 1653-1664. https://doi.org/10.1016/ S0038-0717(01)00086-4.

Barneze, A.S., Mazzetto, A.M., Zani, C.F., Misselbrook, T., Cerri, C.C., 2014. Nitrous oxide emissions from soil due to urine deposition by grazing cattle in Brazil. Atmos. Environ. 92, 394-397. https://doi.org/10.1016/j.atmosenv.2014.04.046.

Barneze, A.S., Minet, E.P., Cerri, C.C., Misselbrook, T., 2015. The effect of nitrification inhibitors on nitrous oxide emissions from cattle urine deposition to grassland under summer conditions in the UK. Chemosphere 119, 122-129. https://doi.org/10.1016/j. chemosphere.2014.06.002.

Bolan, N.S., Saggar, S., Luo, J., Bhandral, R., Singh, J., 2004. Gaseous emissions of nitrogen from grazed pastures: processes, measurements and modelling, environmental implications, and mitigation. Adv. Agron. 84, 37-120. https://doi.org/10.1016/S00652113(04)84002-1.

Carnevalli, R.A., Da Silva, S.C., Bueno, A.A.O., Uebele, M.C., Bueno, F.O., Hodgson, J., Silva, G.N., Morais, J.P.G., 2006. Herbage production and grazing losses in Panicum maximum cv. Mombaça under four grazing management. Trop. Grassl.-Forrajes Trop. 40, 165-176 http://tropicalgrasslands.info/public/journals/4/Historic/Tropical\%20Grasslands\%20Journal\%20archive/PDFs/Vol_40_2006/Vol_40_03_2006_pp165_176.pdf.

Carvalho, P.C.F., 2013. Harry Stobbs memorial lecture: can grazing behavior support innovations in grassland management? Trop. Grassl.-Forrajes Trop. 1, 137-155. https:// doi.org/10.17138/TGFT(1)137-155.

CEPAGRI, 2012. Centro de pesquisas meteorológicas e climáticas aplicadas à agricultura. [Center of Applied Climatic and Meteorological Research in Agriculture]. UNICAMP, Campinashttp://www.cpa.unicamp.br/outras-informacoes/clima_muni_436.html.

Chapman, D., 2016. Using ecophysiology to improve farm efficiency: application in temperate dairy grazing systems. Agriculture 6, 1-19. https://doi.org/10.3390/ agriculture6020017.

Chiavegato, M.B., Powers, W., Carmichael, D., Rowntree, J., 2015. Pasture-derived greenhouse gas emissions in cow-calf production systems. J. Anim. Sci. 93, 1350-1364. https://doi.org/10.2527/jas2014-8134.

Clough, T.J., Lanigan, G.J., de Klein, C.A.M., Samad, M.S., Morales, S.E., Rex, D., Bakken, L.R., Johns, C., Condron, L.M., Grant, J., Richards, K.G., 2017. Influence of soil moisture on codenitrification fluxes from a urea-affected pasture soil. Sci. Rep. 7, 2185. https:// doi.org/10.1038/s41598-017-02278-y.

Conforti, P., 2011. Looking Ahead in World Food and Agriculture: Perspectives to 2050. Food and Agriculture Organization, Rome http://www.fao.org/docrep/014/i2280e/ i2280e.pdf.

Congio, G.F.S., Batalha, C.D.A., Chiavegato, M.B., Berndt, A., Oliveira, P.P.A., Frighetto, R.T.S., Maxwell, T.M.R., Gregorini, P., Da Silva, S.C., 2018. Strategic grazing management towards sustainable intensification at tropical pasture-based dairy systems. Sci. Total Environ. 636, 872-880. https://doi.org/10.1016/j.scitotenv.2018.04.301.

Da Silva, S.C., Bueno, A.A.O., Carnevalli, R.A., Uebele, M.C., Bueno, F.O., Hodgson, J., Matthew, C., Arnold, J.C., Morais, J.P.G., 2009. Sward structural characteristics and herbage accumulation of Panicum maximum cv. Mombaça subject to rotational stocking managements. Sci. Agric. 66, 8-19. https://doi.org/10.1590/ S010390162009000100002.

Da Silva, S.C., Sbrissia, A.F., Pereira, L.E.T., 2015. Ecophysiology of C4 forage grasses-understanding plant growth for optimising their use and management. Agriculture 5, 598-625. https://doi.org/10.3390/agriculture5030598.

Da Silva, S.C., Chiavegato, M.B., Pena, K.S., Silveira, M.C.T., Barbero, L.M., Junior, S.J.S., Rodrigues, C.S., Limão, V.A., Pereira, L.E.T., 2017. Tillering dynamics of Mulato grass subjected to strategies of rotational grazing management. J. Agric. Sci. 155, 1082-1092. https://doi.org/10.1017/S0021859617000223.

Davidson, E.A., 1992. Sources of nitric oxide and nitrous oxide following wetting of dry soil. Soil Sci. Soc. Am. J. 56, 95-102. https://doi.org/10.2136/ sssaj1992.03615995005600010015x.

van der Weerden, T.J., Styles, T.M., Rutherford, A.J., de Klein, C.A.M., Dynes, R., 2017. Nitrous oxide emissions from cattle urine deposited onto soil supporting a winter forage kale crop. N. Z. J. Agric. Res. 60, 119-130. https://doi.org/10.1080/ 00288233.2016 .1273838$.

Di, H.J., Cameron, K.C., 2016. Inhibition of nitrification to mitigate nitrate leaching and nitrous oxide emissions in grazed grassland: a review. J. Soils Sediments 16 , 1401-1420. https://doi.org/10.1007/s11368-016-1403-8.

Di, H.J., Cameron, K.C., Podolyan, A., Edwards, G.R., de Klein, C.A.M., Dynes, R., Woods, R., 2016. The potential of using alternative pastures, forage crops and gibberellic acid to mitigate nitrous oxide emissions. J. Soils Sediments 16, 2252-2262. https://doi.org/ 10.1007/s11368-016-1442-1.

Embrapa, 2018. Brazilian System of Soil Classification. 5th ed. rev. and exp. Embrapa, Brasilia, DF E-book available. https://www.embrapa.br/en/busca-de-publicacoes/-/ publicacao/1094001/brazilian-soil-classification-system.

Flechard, C.R., Ambus, P., Skiba, U., Rees, R.M., Hensen, A., van Amstel, A., Pol-van Dasselaar, A.V., Soussana, J.F., Jones, M., Clifton-Brown, J., Raschi, A., Horvath, L., Neftel, A., Jocher, M., Ammann, C., Leifeld, J., Fuhrer, J., Calanca, P., Thalman, E., Pilegaard, K., Di Marco, C., Campbell, C., Nemitz, E., Hargreaves, K.J., Levy, P.E., Ball, B.C., Jones, S.K., van de Bulk, W.C.M., Groot, T., Blom, M., Domingues, R., Kasper, G., Allard, V., Ceschia, 
E., Cellier, P., Laville, P., Henault, C., Bizouard, F., Abdalla, M., Williams, M., Baronti, S. Berretti, F., Grosz, B., 2007. Effects of climate and management intensity on nitrous oxide emissions in grassland systems across Europe. Agric. Ecosyst. Environ. 121, 135-152. https://doi.org/10.1016/j.agee.2006.12.024.

Flint, A.L., Flint, L.E., 2002. Particle density. In: Dane, J.H., Topp, G.C. (Eds.), Methods of Soil Analysis. Part 4. Physical Methods. SSSA Book Ser. 5. SSSA, Madison, WI, pp. 229-240 https://doi.org/10.2136/sssabookser5.4.c10.

Fonseca, L., Mezzalira, J.C., Bremm, C., Filho, R.S.A., Gonda, H.L., Carvalho, P.C.F., 2012. Management targets for maximising the short-term herbage intake rate of cattle grazing in Sorghum bicolor. Livest. Sci. 145, 205-211. https://doi.org/10.1016/j. livsci.2012.02.003.

Gardiner, C.A., Clough, T.J., Cameron, K.C., Di, H.J., Edwards, G.R., de Klein, C.A.M., 2016. Potential for forage diet manipulation in New Zealand pasture ecosystems to mitigate ruminant urine derived $\mathrm{N}_{2} \mathrm{O}$ emissions: a review. N. Z. J. Agric. Res. 59 (3), 301-317. https://doi.org/10.1080/00288233.2016.1190386.

Gardiner, C.A., Clough, T.J., Cameron, K.C., Di, H.J., Edwards, G.R., de Klein, C.A.M., 2017. Potential inhibition of urine patch nitrous oxide emissions by Plantago lanceolata and its metabolite aucubin. N. Z. J. Agric. Res. 60 (4), 1-9. https:// doi.org/10.1080/00288233.2017.1411953.

Gimenes, F.M.A., Da Silva, S.C., Fialho, C.A., Gomes, M.B., Berndt, A., Gerdes, L., Colozza, M.T., 2011. Ganho de peso e produtividade animal em capim-marandu sob pastejo rotativo e adubação nitrogenada. Pesq. Agropec. Bras. 46, 751-759. https://doi.org/ 10.1590/S0100-204X2011000700011.

Godfray, H., Beddington, J.R., Crute, I.R., Haddad, L., Lawrence, D., Muir, J.F., Pretty, J., Robinson, S., Thomas, S.M., Toulmin, C., 2010. Food security: the challenge of feeding 9 billion people. Science 327, 812-818. https://doi.org/10.1126/science.1185383.

Gregorini, P., Beukes, P.C., Dalley, D., Romera, A.J., 2016. Screening for diets that reduce urinary nitrogen excretion and methane emissions while maintaining or increasing production by dairy cows. Sci. Total Environ. 551-552, 32-41. https://doi.org/ 10.1016/j.scitotenv.2016.01.203.

Grossman, R.B., Reinsch, T.G., 2002. Bulk density and linear extensibility. In: Dane, J.H., Topp, G.C. (Eds.), Methods of Soil Analysis. Part 4. Physical Methods. SSSA Book Ser. 5. SSSA, Madison, WI, pp. 201-228 https://doi.org/10.2136/sssabookser5.4.c10.

Guerci, M., Knudsen, M.T., Bava, L., Zucali, M., Schonbach, P., Kristensen, T., 2013. Parameters affecting the environmental impact of a range of dairy farming systems in Denmark, Germany and Italy. J. Clean. Prod. 54, 133-141. https://doi.org/10.1016/j. jclepro.2013.04.035.

Jolliffe, I.T., 2002. Principal Component Analysis. 2nd ed. Springer-Verlag, New York, p. 518. http://cda.psych.uiuc.edu/statistical_learning_course/Jolliffe\%20I.\%20Principal \%20Component\%20Analysis\%20(2ed.\%20Springer,\%202002)(518s)_MVsa_.pdf.

de Klein, C.A.M., Eckard, R.J., 2008. Targeted technologies for nitrous oxide abatement from animal agriculture. Aust. J. Exp. Agric. 48, 14-20. https://doi.org/10.1071/ EA07217.

de Klein, C.A.M., Harvey, M., 2015. Nitrous Oxide Chamber Methodology Guidelines. Ministry for Primary Industries, Pastoral House, 25 The Terrace, PO Box 2526, Wellington 6140, New Zealand, p. 146. https://globalresearchalliance.org/wp-content/uploads/ 2015/11/Chamber_Methodology_Guidelines_Final-V1.1-2015.pdf.

de Klein, C.A.M., Pinares-Patino, C., Waghorn, G.C., 2008. Greenhouse gas emissions. In: McDowell, R.W. (Ed.), Environmental Impacts of Pasture Based Farming. CAB International, Wallingford, Oxfordshire, UK, pp. 1-32 https://doi.org/10.1079/ 9781845934118.0001

de Klein, C.A.M., Luo, J., Woodward, K.B., Styles, T., Wise, B., Lindsey, S., Cox, N., 2014. The effect of nitrogen concentration in synthetic cattle urine on nitrous oxide emissions. Agric. Ecosyst. Environ. 188, 85-92. https://doi.org/10.1016/j.agee.2014.02.020.

Lessa, A.C.R., Madari, B.E., Paredes, D.S., Boddey, R.M., Urquiaga, S., Jantalia, C.P., Alves, B.J.R., 2014. Bovine urine and dung deposited on Brazilian savannah pastures contribute differently to direct and indirect soil nitrous oxide emissions. Agric. Ecosyst. Environ. 190, 104-111. https://doi.org/10.1016/j.agee.2014.01.010.

Levine, U.Y., Teal, T.K., Robertson, G.P., Schmidt, T.M., 2011. Agriculture's impact on microbial diversity and associated fluxes of carbon dioxide and methane. ISME J 5 , 1683-1691. https://doi.org/10.1038/ismej.2011.40.

Luo, J., Wyatt, J., van der Weerden, T., Thomas, S., de Klein, C., Li, Y., Rollo, M., Lindsey, S., Ledgard, S., Li, J., Ding, W., Qin, S., Zhang, N., Bolan, N., Kirkham, M.B., Bai, Z., Ma, L., Zhang, X., Wang, H., Liu, H., Rys, G., 2017. Potential hotspot areas of nitrous oxide emissions from grazed pastoral dairy farm systems. Adv. Agron. 145, 205-268. https://doi.org/10.1016/bs.agron.2017.05.006.

Luo, J., Balvert, S.F., Wise, B., Welten, B., Ledgard, S.F., de Klein, C.A.M., Lindsey, S., Judge, A., 2018. Using alternative forage species to reduce emissions of the greenhouse gas nitrous oxide from cattle urine deposited onto soil. Sci. Total Environ. 610-611, 1271-1280. https://doi.org/10.1016/j.scitotenv.2017.08.186.

Macdonald, K.A., Penno, J.W., Lancaster, J.A.S., Bryant, A.M. Kidd, J.M., Roche, J.R., 2017. Production and economic responses to intensification of pasture-based dairy production systems. J. Dairy Sci. 100, 6602-6619. https://doi.org/10.3168/jds.2016-12497.

Mazzetto, A.M., Barneze, A.S., Feigl, B.J., van Groenigen, J.W., Oenema, O., Cerri, C.C., 2014. Temperature and moisture affect methane and nitrous oxide emission from bovine manure patches in tropical conditions. Soil Biol. Biochem. 76, 242-248. https://doi. org/10.1016/j.soilbio.2014.05.026.

Mazzetto, A.M., Barneze, A.S., Feigle, B.J., van Groenigen, J.W., Oenema, O., de Klein, C.A.M. Cerri, C.C., 2015. Use of the nitrification inhibitor dicyandiamide (DCD) does not mitigate $\mathrm{N} 2 \mathrm{O}$ emission from bovine urine patches under Oxisol in Northwest Brazil. Nutr. Cycl. Agroecosyst. 101, 83-92. https://doi.org/10.1007/s10705-014-9663-4.

O'Brien, D., Shalloo, L., Patton, J., Buckley, F., Grainger, C., Wallace, M., 2012. A life cycle assessment of seasonal grass-based and confinement dairy farms. Agric. Syst. 107, 33-46. https://doi.org/10.1016/j.agsy.2011.11.004.

OECD, 2017. OECD Environmental Performance Reviews: New Zealand 2017. OECD Publishing, Paris https://doi.org/10.1787/9789264268203-en.
Parsons, A., Rowarth, J., Thornley, J., Newton, P., 2011. Primary production of grasslands, herbage accumulation and use, and impacts of climate change. In: Lemaire, G. Hodgson, J., Chabbi, A. (Eds.), Grassland Productivity and Ecosystem Services, 1st edn Cabi, Wallingford, UK, p. 436 https://doi.org/10.1079/9781845938093.A.

Pereira, L.E.T., Paiva, A.J., Geremia, E.V., Da Silva, S.C., 2014. Components of herbage accumulation in elephant grass cvar Napier subjected to strategies of intermittent stocking management. J. Agric. Sci. 152, 954-966. https://doi.org/10.1017/ S0021859613000695.

Pereira, L.E.T., Paiva, A.J., Geremia, E.V., Da Silva, S.C., 2015. Regrowth patterns of elephant grass (Pennisetum purpureum Schum.) subjected to strategies of intermittent stocking management. Grass Forage Sci. 70, 195-204. https://doi.org/10.1111/gfs.12103.

Rafique, R., Hennessy, D., Kiely, G., 2011. Nitrous oxide emission from grazed grassland under different management systems. Ecosystems 14, 563-582. https://doi.org/ 10.1007/s10021-011-9434-x.

Ramsbottom, G., Horan, B., Berry, D.P., Roche, J.R., 2015. Factors associated with the financial performance of spring-calving, pasture-based dairy farms. J. Dairy Sci. 98, 3526-3540. https://doi.org/10.3168/jds.20148516.

Rex, D., Clough, T.J., Richards, K.G., de Klein, C.A.M., Morales, S.E., Samad, M.S., Grant, J., Lanigan, G.J., 2018. Fungal and bacterial contributions to codenitrification emissions of N2O and N2 following urea deposition to soil. Nutr. Cycl. Agroecosyst. 110 (1) 135-149. https://doi.org/10.1007/s10705-017-9901-7.

Saggar, S., Jha, N., Deslippe, J., Bolan, N.S., Luo, J., Giltrap, D.L., Kim, D.G., Zaman, M., Tillman, R.W., 2013. Denitrification and N2O:N2 production in temperate grasslands: process, measurements, modelling and mitigating negative impacts. Sci. Total Environ. 465, 173-195. https://doi.org/10.1016/j.scitotenv.2012.11.050.

Samad, M.D.S., Biswas, A., Bakken, L.R., Clough, T.J., de Klein, C.A.M., Richards, K.G. Lanigan, G.J., Morales, S.E., 2016. Phylogenetic and functional potential links $\mathrm{pH}$ and N2O emissions in pasture soils. Sci. Rep. 6, 35990. https://doi.org/10.1038/srep35990.

Santos, F.A.P., Dorea, J.R.R., de Souza, J.. Batistel, F., Costa, D.F.A., 2014. Forage management and methods to improve nutrient intake in grazing cattle. Proceedings of the 25th Annual Florida Ruminant Nutrition Symposium. University of Florida, Gainesville, United States of America , pp. 144-164. http://dairy.ifas.ufl.edu/rns/2014/santos.pdf.

Sbrissia, A.F., Duchini, P.G. Zanini, G.D., Santos, G.T., Padilha, D.A. Schimitt, D. 2018. Defoliation strategies in pastures submitted to intermittent stocking method: underlying mechanisms buffering forage accumulation over a range of grazing heights. Crop Sci. 58, 1-10. https://doi.org./10.2135/cropsci2017.07.0447.

Schmalz, H.J., Taylor, R.V., Johnson, T.N., Kennedy, P.L., DeBano, S.J., Newingham, B.A. McDaniel, P.A., 2013. Soil morphologic properties and cattle stocking rate affect dynamic soil properties. Rangeland Ecol. Manag. 66 (4), 445-453. https://doi.org/ 10.2111/REM-D-12-00040.1.

Selbie, D., 2013. The Fate of Nitrogen in an Animal Urine Patch as Affected by Urine Nitrogen Loading Rate and the Nitrification Inhibitor Dicyandiamide. Lincoln University (PhD). http://researcharchive.lincoln.ac.nz/handle/10182/5950.

Selbie, D.R., Buckthought, L.E., Shepherd, M.A., 2015. The challenge of the urine patch for managing nitrogen in grazed pasture systems. Adv. Agron. 129, 229-292. https://doi. org/10.1016/bs.agron.2014.09.004.

Silva, A.P., Imhoff, S., Corsi, M., 2003. Evaluation of soil compaction in irrigated shortduration grazing system. Soil Tillage Res. 70, 83-90. https://doi.org/10.1016/S01671987(02)00122-8.

Silveira, M.C.T., Da Silva, S.C., Souza Jr., S.J., Barbero, L.M., Rodrigues, C.S., Limão, V.A., Pena K.S., Nascimento Jr., D., 2013. Herbage accumulation and grazing losses on Mulato grass subjected to strategies of rotational stocking management. Sci. Agric. 70: 242-249. doi:https://doi.org/10.1590/S0103-90162013000400004.

Smith, P., Goulding, K.W., Smith, K.A., Powlson, D.S., Smith, J.U., Falloon, P., Coleman, K. 2001. Enhancing the carbon sink in European agricultural soils: including trace gas fluxes in estimates of carbon mitigation potential. Nutr. Cycl. Agroecosyst. 60 237-252. https://doi.org/10.1023/A:1012617517839.

Trindade, J.K., Da Silva, S.C., Souza Jr., S.J., Giacomini, A.A., Zeferino, C.V., Guarda, V.D.A. Carvalho, P.C.F., 2007. Composição morfológica da forragem consumida por bovinos de corte durante o rebaixamento do capim-marandu submetido a estratégias de pastejo rotativo. Pesq. Agropec. Bras. 42, 883-890. https://doi.org/10.1590/ S0100204X2007000600016.

Venterea, R., Clough, T.J., Coulter, J.A., Breuillin-Sessoms, F., Wang, P., Sadowsky, M.J. 2015. Ammonium sorption and ammonia inhibition of nitrite-oxidizing bacteria explain contrasting soil N2O production. Sci. Rep. 5, 12153. https://doi.org/10.1038/ srep12153.

Venterea, R.T., 2010. Simplified method for quantifying theoretical underestimation of chamber-based trace gas fluxes. J. Environ. Qual. 39, 126-135. https://doi.org/ 10.2134/jeq2009.0231.

Vibart, R.E., Tavendale, M., Otter, D., Schwendel, B.H., Lowe, K., Gregorini, P., Pacheco, D. 2017. Milk production and composition, nitrogen utilization, and grazing behavio of late-lactation dairy cows as affected by time of allocation of a fresh strip of pasture. J. Dairy Sci. 100, 1-14. https://doi.org/10.3168/jds.2016-12413.

Voltolini, T.V., Santos, F.A.P., Martinez, J.C., Imaizumi, H., Clarindo, R.L., Penati, M.A., 2010 Produção e composicão do leite de vacas mantidas em pastagens de capim-elefante submetidas a duas frequências de pastejo. Rev. Bras. Zootecn. 39 (1), 121-127. https://doi.org/10.1590/S1516-35982010000100016.

Warren, S.D. Thurow, T.L, Blackburn, W.H., Garza, N.E, 1986. The influence of livestock trampling under intensive rotation grazing on soil hydrologic characteristics. J. Range Manag. 39, 491-495. https://doi.org/10.2307/3898755.

White, S.L., Sheffield, R.E., Washburn, S.P., King, L.D., Green, J.T., 2001. Spatial and time distribution of dairy cattle excreta in an intensive pasture system. J. Environ. Qual. 30, 2180-2187. https://doi.org/10.2134/jeq2001.2180.

Wrage, N., Velthof, G.L., van Beusichem, M.L., Oenema, O., 2001. Role of nitrifier denitrification in the production of nitrous oxide. Soil Biol. Biochem. 33, 1723-1732. https:// doi.org/10.1016/S0038-0717(01)00096-7. 